Supporting Information for:

\title{
Oxidative C-H Activation/C-C Bond Forming Reactions: Synthetic Scope and Mechanistic Insights
}

\author{
Dipannita Kalyani, Nick Deprez, Lopa V. Desai, and Melanie S. Sanford* \\ Department of Chemistry, University of Michigan, 930 North University Avenue, Ann Arbor, \\ MI 48109
}

General Procedures: NMR spectra were obtained on a Varian Inova $500\left(499.90 \mathrm{MHz}\right.$ for ${ }^{1} \mathrm{H} ; 125.70 \mathrm{MHz}$ for $\left.{ }^{13} \mathrm{C}\right)$ or a Varian Inova $400\left(399.96 \mathrm{MHz}\right.$ for ${ }^{1} \mathrm{H}$; $100.57 \mathrm{MHz}$ for $\left.{ }^{13} \mathrm{C}\right)$ spectrometer. ${ }^{1} \mathrm{H}$ NMR chemical shifts are reported in parts per million (ppm) relative to TMS, with the residual solvent peak used as an internal reference. Multiplicities are reported as follows: singlet (s), doublet (d), doublet of doublets (dd), doublet of triplets $(\mathrm{dt})$, triplet $(\mathrm{t})$, quartet $(\mathrm{q})$, multiplet $(\mathrm{m})$, and broad resonance $(\mathrm{br})$.

Materials and Methods: Substrates 5, 7, 8, 11, 12, and 13 were obtained from commercial sources and used as received. Substrate 1 was prepared by Suzuki cross-coupling of phenyl boronic acid and 2bromo-3-methylpyridine according to a literature procedure. ${ }^{1}$ Pyridine substrates 2, 3 and 4 were prepared by Stille cross-coupling of 2-tributylpyridyltin with the corresponding aryl bromides. ${ }^{2}$ Amide substrates 9 and 10 were prepared by palladium-catalyzed arylation of the corresponding lactam. ${ }^{3}$ Phenyl iodonium salts were prepared by the reaction of $\mathrm{PhI}(\mathrm{OAc})_{2}$ with $\operatorname{ArB}(\mathrm{OH})_{2}$ in the presence of $\mathrm{BF}_{3} \cdot \mathrm{Et}_{2} \mathrm{O}$ (for $\left[\mathrm{Ph}_{2} \mathrm{I}\right] \mathrm{BF}_{4}$, $\left[\mathrm{Ph}-\mathrm{I}-p-\mathrm{FC}_{6} \mathrm{H}_{4}\right] \mathrm{BF}_{4}$, $\left[\mathrm{Ph}-\mathrm{I}-p-\mathrm{ClC}_{6} \mathrm{H}_{4}\right] \mathrm{BF}_{4}$, $\left[\mathrm{Ph}-\mathrm{I}-o-\mathrm{CH}_{3} \mathrm{C}_{6} \mathrm{H}_{5}\right] \mathrm{BF}_{4}$, $\left.\left[\mathrm{Ph}-\mathrm{I}-p-\mathrm{CH}_{3} \mathrm{C}_{6} \mathrm{H}_{5}\right] \mathrm{BF}_{4}\right)^{4}$ or trifluoromethanesulfonic acid (for $\left[\mathrm{Ph}-\mathrm{I}-p-\mathrm{MeOC}_{6} \mathrm{H}_{4}\right] \mathrm{BF}_{4}$ and $\left[\mathrm{Ph}-\mathrm{I}-\right.$ thienyl] $\mathrm{BF}_{4}$ ). ${ }^{5}$ Mesityl iodonium salts were prepared by the reaction of $\operatorname{MesI}(\mathrm{OAc})_{2}{ }^{6}$ with $\mathrm{ArB}(\mathrm{OH})_{2}$ in the presence of $\mathrm{BF}_{3} \bullet \mathrm{Et}_{2} \mathrm{O}$ (for [Mes-I- $p$ $\left.\mathrm{FC}_{6} \mathrm{H}_{4}\right] \mathrm{BF}_{4}, \quad\left[\mathrm{Mes}-\mathrm{I}-p-\mathrm{ClC}_{6} \mathrm{H}_{4}\right] \mathrm{BF}_{4}, \quad\left[\mathrm{Mes}-\mathrm{I}-o-\mathrm{CH}_{3} \mathrm{C}_{6} \mathrm{H}_{5}\right] \mathrm{BF}_{4}, \quad\left[\mathrm{Mes}-\mathrm{I}-\mathrm{p}-\mathrm{CH}_{3} \mathrm{C}_{6} \mathrm{H}_{5}\right] \mathrm{BF}_{4}$, [Mes-I-(1napthyl) $] \mathrm{BF}_{4}$, by reaction of $\mathrm{PhI}(\mathrm{OAc})_{2}$ with mesitylene in $\mathrm{H}_{2} \mathrm{SO}_{4},{ }^{7}$ or by reaction of $\mathrm{MesI}(\mathrm{OAc})_{2}$ with anisole in $\mathrm{CH}_{2} \mathrm{Cl}_{2}$ /trifluoroacetic acid. ${ }^{8} \mathrm{Pd}(\mathrm{OAc})_{2}$ was obtained from Pressure Chemical and used as received and $\mathrm{PhI}(\mathrm{OAc})_{2}$ was obtained from Acros and used as received. Mercury (electrochemical grade, 99.9999\%) was obtained from Aldrich and used as received. Solvents were obtained from Fisher Chemical and used without further purification. Flash chromatography was performed on EM Science silica gel 60 (0.040-0.063 mm particle size, 230-400 mesh) and thin layer chromatography was performed on Merck TLC plates pre-coated with silica gel $60 \mathrm{~F}_{254}$. Control reactions (in the absence of Pd catalyst) were run for 
each substrate, and generally showed no reaction under our standard conditions. In general, crude reaction mixtures were filtered through glass wool or Celite to remove insoluble materials that form at the end of the reaction before workup.

\section{Experimental Procedures}

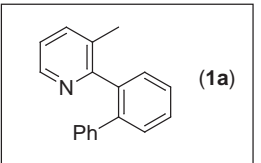

Product 1a. Substrate 1 (200 mg, $1.18 \mathrm{mmol}, 1$ equiv), [ $\left.\mathrm{Ph}_{2} \mathrm{I}\right] \mathrm{BF}_{4}$ (500 mg, $1.36 \mathrm{mmol}, 1.15 \mathrm{equiv}$ ) and $\mathrm{Pd}(\mathrm{OAc})_{2}(13.2 \mathrm{mg}, 0.059 \mathrm{mmol}, 5 \mathrm{~mol} \%)$ were combined in acetic acid $(10 \mathrm{~mL})$ in a $20 \mathrm{~mL}$ vial. The vial was sealed with a Teflon lined cap, and the reaction was stirred at $100^{\circ} \mathrm{C}$ for 12 hours. The reaction mixture was filtered through a plug of Celite and then concentrated under vacuum. The resulting crude oil was dissolved in $\mathrm{CH}_{2} \mathrm{Cl}_{2}$ and extracted with saturated aqueous $\mathrm{NaHCO}_{3}(2 \times 30 \mathrm{~mL})$ and brine $(1 \times 30$ $\mathrm{mL}$ ). The organic layer was dried over $\mathrm{MgSO}_{4}$, filtered, and concentrated to afford an orange oil, which was purified by chromatography on silica gel $\left(\mathrm{R}_{\mathrm{f}}=0.2\right.$ in $95 \% \mathrm{CH}_{2} \mathrm{Cl}_{2} / 5 \%$ ethyl acetate). The product was obtained as a viscous yellow oil (255 mg, $88 \%$ yield); ${ }^{1} \mathrm{H}$ NMR ( $d_{6}$-acetone): $\delta 8.47(\mathrm{~d}, J=4.8 \mathrm{~Hz}, 1 \mathrm{H})$, 7.55-7.43 (multiple peaks, $3 \mathrm{H}), 7.40(\mathrm{~d}, J=7.5 \mathrm{~Hz}, 1 \mathrm{H}), 7.37-7.35(\mathrm{~m}, 1 \mathrm{H}), 7.21-7.10$ (multiple peaks, $6 \mathrm{H}$ ), $1.75(\mathrm{~s}, 3 \mathrm{H}) .{ }^{13} \mathrm{C}\left\{{ }^{1} \mathrm{H}\right\}$ NMR ( $d_{6}$-acetone): $\delta 161.29,148.19,142.99,142.40,141.62,139.03,133.06,131.80$, 131.32, 130.92, 130.04, 129.58, 128.98, 128.48, 124.00, 19.95. Anal. Calcd for $\mathrm{C}_{18} \mathrm{H}_{15} \mathrm{~N}$ : C, 88.13, H, 6.16, N, 5.71; Found: C, 88.15, H, 6.17, N, 5.43. IR (thin film) $1418 \mathrm{~cm}^{-1}$.

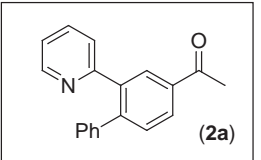

Product 2a. Substrate 2 (150 mg, $0.76 \mathrm{mmol}, 1$ equiv), [ $\left.\mathrm{Ph}_{2} \mathrm{I}\right] \mathrm{BF}_{4}(420 \mathrm{mg}, 1.14 \mathrm{mmol}, 1.5$ equiv), and $\mathrm{Pd}(\mathrm{OAc})_{2}(8.5 \mathrm{mg}, 0.038 \mathrm{mmol}, 5 \mathrm{~mol} \%)$ were combined in acetic acid $(6 \mathrm{~mL})$ in a $20 \mathrm{~mL}$ vial. The vial was sealed with a Teflon lined cap and the reaction was heated at $100^{\circ} \mathrm{C}$ for 2 days. The reaction mixture was filtered through a plug of Celite and then evaporated to dryness. The resulting oil was dissolved in $\mathrm{CH}_{2} \mathrm{Cl}_{2}$ and extracted with saturated aqueous $\mathrm{NaHCO}_{3}(2 \times 30 \mathrm{~mL})$ and brine $(1 \times 30 \mathrm{~mL})$. The organic layer was dried over $\mathrm{MgSO}_{4}$, filtered, and concentrated to afford an orange oil, which was purified by chromatography on silica gel $\left(\mathrm{R}_{\mathrm{f}}=0.25\right.$ in $88 \% \mathrm{CH}_{2} \mathrm{Cl}_{2} / 12 \%$ ethyl acetate). The product was obtained as an orange/brown solid (189 mg, 91\% yield); mp 77-78 ${ }^{\circ} \mathrm{C} .{ }^{1} \mathrm{H}$ NMR (acetone- $\left.d_{6}\right): \delta 8.59-8.57(\mathrm{~m}, 1 \mathrm{H}), 8.07$ $(\mathrm{dd}, J=8.0,1.9 \mathrm{~Hz}, 1 \mathrm{H}), 8.24(\mathrm{~d}, J=1.8 \mathrm{~Hz}, 1 \mathrm{H}), 7.55(\mathrm{~d}, J=8.0,1 \mathrm{H}), 7.50(\mathrm{td}, J=7.7,1.8 \mathrm{~Hz}, 1 \mathrm{H}), 7.26-7.25$ $(\mathrm{m}, 3 \mathrm{H}), 7.21-7.18(\mathrm{~m}, 1 \mathrm{H}), 7.16-7.13(\mathrm{~m}, 2 \mathrm{H}), 6.96-6.93(\mathrm{~m}, 1 \mathrm{H}), 2.63(\mathrm{~s}, 3 \mathrm{H}) .{ }^{13} \mathrm{C}\left\{{ }^{1} \mathrm{H}\right\} \mathrm{NMR}\left(\mathrm{CDCl}_{3}\right): \delta$ 
197.80, 158.50, 149.81, 145.36, 140.37, 139.93, 136.43, 135.63, 131.12, 129.64, 128.44, 128.18, 127.64, 125.49, 122.99, 26.96. HRMS-electrospray $(m / z)$ : $\left[\mathrm{M}^{+}+\mathrm{H}\right]$ calcd for $\mathrm{C}_{19} \mathrm{H}_{15} \mathrm{NO}, 274.1232$; found, 274.1233. Anal. Calcd for $\mathrm{C}_{19} \mathrm{H}_{15} \mathrm{NO}$ : C, 83.94, H, 5.53, N, 5.12; Found: C, 83.56, H, 5.45, N, 5.04. IR (KBr) 1683, $1586 \mathrm{~cm}^{-1}$.

The regioselectivity of this reaction could not be definitively determined from the ${ }^{1} \mathrm{H}$ NMR spectrum of 2a due to overlapping aromatic resonances. As a result, a deuterated version of this product was prepared by reaction of 2 with [Mes-I- $\left.\mathrm{C}_{6} \mathrm{D}_{5}\right] \mathrm{BF}_{4}$ under analogous conditions to those described above. The ${ }^{1} \mathrm{H}$ NMR data for the deuterated product (2a- $\left.d_{5}\right)$ was as follows: ${ }^{1} \mathrm{H}$ NMR ( $d_{6}$-acetone): $\delta$ 8.69$8.67(\mathrm{~m}, 1 \mathrm{H}), 8.30(\mathrm{~d}, J=2.0 \mathrm{~Hz}, 1 \mathrm{H}), 8.17(\mathrm{dd}, J=8.0,2.0 \mathrm{~Hz}, 1 \mathrm{H}), 7.68(\mathrm{~d}, J=8 \mathrm{~Hz}, 1 \mathrm{H}), 7.63(\mathrm{dt}, J=7.5$, $1.5 \mathrm{~Hz}, 1 \mathrm{H})$, 7.34-7.32 (m, 1H), 7.15-7.13 (m, 1H).

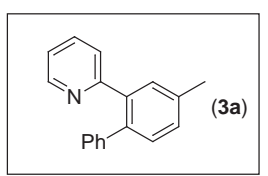

Product 3a. Substrate 3 (150 mg, $0.89 \mathrm{mmol}, 1$ equiv), [ $\left.\mathrm{Ph}_{2} \mathrm{I}\right] \mathrm{BF}_{4}(489 \mathrm{mg}, 1.33 \mathrm{mmol}, 1.5$ equiv), and $\mathrm{Pd}(\mathrm{OAc})_{2}(9.9 \mathrm{mg}, 0.044 \mathrm{mmol}, 5 \mathrm{~mol} \%)$ were combined in acetic acid $(4 \mathrm{~mL})$ and acetic anhydride $(4 \mathrm{~mL})$ in a $20 \mathrm{~mL}$ vial. The vial was sealed with a Teflon lined cap and the reaction was heated at $100^{\circ} \mathrm{C}$ for 12 hours. The reaction mixture was filtered through a plug of Celite and then evaporated to dryness. The resulting oil was dissolved in $\mathrm{CH}_{2} \mathrm{Cl}_{2}$ and extracted with saturated aqueous $\mathrm{NaHCO}_{3}(2 \times 30 \mathrm{~mL})$ and brine $(1 \times 30 \mathrm{~mL})$. The organic layer was dried over $\mathrm{MgSO}_{4}$, filtered, and concentrated to afford a yellow oil, which was purified by chromatography on silica gel $\left(\mathrm{R}_{\mathrm{f}}=0.24\right.$ in $97.5 \% \mathrm{CH}_{2} \mathrm{Cl}_{2} / 2.5 \%$ ethyl acetate). The product was obtained as a brown solid $\left(156 \mathrm{mg}, 74 \%\right.$ yield); mp 80-84 ${ }^{\circ} \mathrm{C} .{ }^{1} \mathrm{H}$ NMR $\left(\mathrm{C}_{6} \mathrm{D}_{6}\right): \delta 8.58(\mathrm{~d}, J$ $=4.8 \mathrm{~Hz}, 1 \mathrm{H}), 7.79(\mathrm{~s}, 1 \mathrm{H}), 7.27(\mathrm{~d}, J=7.8 \mathrm{~Hz}, 1 \mathrm{H}), 7.22-7.20(\mathrm{~m}, 2 \mathrm{H}), 7.04-6.95$ (multiple peaks, $4 \mathrm{H}), 6.83-$ $6.79(\mathrm{~m}, 2 \mathrm{H}), 6.77-6.75(\mathrm{~m}, 1 \mathrm{H}), 2.17(\mathrm{~s}, 3 \mathrm{H}) .{ }^{13} \mathrm{C}\left\{{ }^{1} \mathrm{H}\right\} \mathrm{NMR}\left(\mathrm{CDCl}_{3}\right): \delta 158.88,148.94,140.85,138.76,137.36$, $136.92,134.68,130.66,130.03,129.28,128.86,127.59,126.08,125.04,120.84,20.66$. HRMS-electrospray $(\mathrm{m} / \mathrm{z})$ : $\left[\mathrm{M}^{+}+\mathrm{H}\right]$ calcd for $\mathrm{C}_{18} \mathrm{H}_{15} \mathrm{~N}$, 246.1283; found, 246.1290. IR (KBr) $1584 \mathrm{~cm}^{-1}$.

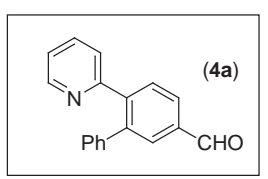

Product 4a. Substrate 4 (200 mg, 1.09 mmol, 1 equiv), [ $\left.\mathrm{Ph}_{2} \mathrm{I}\right] \mathrm{BF}_{4}$ (441 mg, $1.20 \mathrm{mmol}, 1.1$ equiv), and $\mathrm{Pd}(\mathrm{OAc})_{2}(12.2 \mathrm{mg}, 0.054 \mathrm{mmol}, 5 \mathrm{~mol} \%)$ were combined in $\mathrm{AcOH}(9 \mathrm{~mL})$ in a $20 \mathrm{~mL}$ vial. The vial was sealed with a Teflon lined cap, and the reaction was heated at $100^{\circ} \mathrm{C}$ overnight. GC analysis at the completion of the reaction showed $11 \%$ starting material (4), $67 \%$ mono-arylated product (4a) and $21 \%$ of the analogous diarylated product. The reaction mixture was filtered through a plug of Celite and 
evaporated to dryness. The resulting oil was dissolved in $\mathrm{CH}_{2} \mathrm{Cl}_{2}$ and extracted with saturated aqueous $\mathrm{NaHCO}_{3}(2 \times 30 \mathrm{~mL})$ and brine $(1 \times 30 \mathrm{~mL})$. The organic extracts were dried over $\mathrm{MgSO}_{4}$ and concentrated under vacuum to afford a yellow oil, which was purified by chromatography on silica gel $\left(R_{\mathrm{f}}=0.25 \mathrm{in} 65 \%\right.$ hexanes $/ 35 \%$ ethyl acetate). The product was obtained as pale yellow solid (142 $\mathrm{mg}$, $51 \%$ yield); mp 90-94 ${ }^{\circ} \mathrm{C} .{ }^{1} \mathrm{H}$ NMR $\left(\mathrm{C}_{6} \mathrm{D}_{6}\right): \delta 9.71(\mathrm{~s}, 1 \mathrm{H}), 8.51-8.49(\mathrm{~m}, 1 \mathrm{H}), 7.87(\mathrm{~d}, J=9.7 \mathrm{~Hz}, 1 \mathrm{H}), 7.74(\mathrm{~d}, J$ $=1.5 \mathrm{~Hz}, 1 \mathrm{H}), 7.61(\mathrm{dd}, J=7.9,1.5,1 \mathrm{H}), 7.04-7.01(\mathrm{~m}, 2 \mathrm{H}), 6.99-6.96$ (multiple peaks, 3H), 6.74-6.66 (m, 2H), 6.52-6.28 (m, 1H). ${ }^{13} \mathrm{C}\{1 \mathrm{H}\}$ NMR $\left(\mathrm{CDCl}_{3}\right): \delta 191.60,157.49,149.32,144.64,141.15,139.63,135.77,135.11$, 131.60, 131.08, 129.17, 128.14, 127.97, 127.01, 124.97, 121.78. HRMS-electrospray $(m / z):\left[\mathrm{M}^{+}-\mathrm{H}\right]$ calcd for $\mathrm{C}_{18} \mathrm{H}_{13} \mathrm{NO}$, 258.0919; found, 258.0922. IR (KBr): 1696, $1585 \mathrm{~cm}^{-1}$.

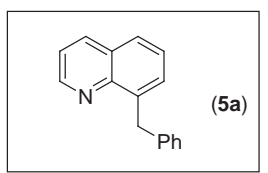

Product 5a. Substrate 5 (619 mg, $4.32 \mathrm{mmol}, 2$ equiv), [ $\left.\mathrm{Ph}_{2} \mathrm{I}\right] \mathrm{BF}_{4}\left(794 \mathrm{mg}, 2.16 \mathrm{~mol}, 1\right.$ equiv) and $\mathrm{Pd}(\mathrm{OAc})_{2}$ ( $24 \mathrm{mg}, 0.108 \mathrm{mmol}, 5 \mathrm{~mol} \%$ ) were combined in a solution of benzene $(9 \mathrm{~mL})$ and acetic anhydride $(9 \mathrm{~mL})$ in a sealed container with a Teflon lined cap, and the reaction was stirred at $100^{\circ} \mathrm{C}$ for 12 hours. The reaction mixture was filtered through a plug of glass wool, and the resulting solution was concentrated under vacuum to afford a yellow oil, which was purified by chromatography on silica gel $\left(R_{\mathrm{f}}=0.22\right.$ in $70 \% \mathrm{CH}_{2} \mathrm{Cl}_{2} / 30 \%$ hexanes). The product was obtained as a brown-orange solid ( $337 \mathrm{mg}, 72 \%$ yield based on $\left.\left[\mathrm{Ph}_{2} \mathrm{I}\right] \mathrm{BF}_{4}\right)$; mp: $52-53{ }^{\circ} \mathrm{C} .{ }^{1} \mathrm{H}$ NMR (d6-acetone): $\delta 8.96(\mathrm{dd}, J=4.2,1.8 \mathrm{~Hz}, 1 \mathrm{H}), 8.26(\mathrm{dd}, J=8.3,1.8 \mathrm{~Hz}$, $1 \mathrm{H}), 7.78(\mathrm{dd}, J=8.1,1.4 \mathrm{~Hz}, 1 \mathrm{H}), 7.58-7.55(\mathrm{~m}, 1 \mathrm{H}), 7.50-7.45$ (multiple peaks, 2H), 7.38-7.36 (m, 2H), 7.26$7.22(\mathrm{~m}, 2 \mathrm{H}), 7.17-7.12(\mathrm{~m}, 1 \mathrm{H}), 4.69(\mathrm{~s}, 2 \mathrm{H}) .{ }^{13} \mathrm{C}\left\{{ }^{1} \mathrm{H}\right\}$ NMR (d6-acetone): $\delta$ 151.36, 148.41, 143.67, 142.07, 137.91, 131.17, 130.88, 130.29, 129.96, 128.23, 128.12, 127.48, 122.97, 38.18. Anal. Calcd for $\mathrm{C}_{16} \mathrm{H}_{13} \mathrm{~N}$ : C, 87.64, H, 5.98, N, 6.39; Found: C, 87.63, H, 5.91, N, 6.35. IR (KBr) 1497, $1491 \mathrm{~cm}^{-1}$.

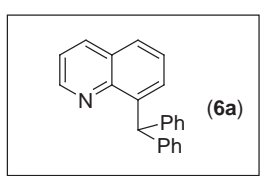

Product 6a. Substrate 5a (182 mg, $0.83 \mathrm{mmol}, 1$ equiv), [ $\left.\mathrm{Ph}_{2} \mathrm{I}\right] \mathrm{BF}_{4}(367 \mathrm{mg}, 1.00 \mathrm{mmol}, 1.2 \mathrm{equiv})$, and $\mathrm{Pd}(\mathrm{OAc})_{2}(9.3 \mathrm{mg}, 0.042 \mathrm{mmol}, 5 \mathrm{~mol} \%)$ were combined in acetic acid $(3.5 \mathrm{~mL})$ and acetic anhydride $(3.5$ $\mathrm{mL}$ ) in a $20 \mathrm{~mL}$ vial. The vial was sealed with a Teflon lined cap and the reaction was heated at $100^{\circ} \mathrm{C}$ for 12 hours. The reaction mixture was filtered through a plug of Celite and then evaporated to dryness. The resulting oil was dissolved in $\mathrm{CH}_{2} \mathrm{Cl}_{2}$ and extracted with saturated aqueous $\mathrm{NaHCO}_{3}(2 \times 30 \mathrm{~mL})$ and 
brine $(1 \times 30 \mathrm{~mL})$. The organic layer was dried over $\mathrm{MgSO}_{4}$, filtered, and concentrated to afford a pale yellow oil, which was purified by chromatography on silica gel $\left(\mathrm{R}_{\mathrm{f}}=0.22\right.$ in $50 \% \mathrm{CH}_{2} \mathrm{Cl}_{2} / 50 \%$ hexanes$)$. The product was obtained as a white solid $\left(147 \mathrm{mg}, 60 \%\right.$ yield); $\mathrm{mp} 135-137^{\circ} \mathrm{C} .{ }^{1} \mathrm{H}$ NMR $\left(\mathrm{CDCl}_{3}\right): \delta 8.97$ $(\mathrm{d}, J=3.9 \mathrm{~Hz}, 1 \mathrm{H}), 8.17(\mathrm{~d}, J=8.2 \mathrm{~Hz}, 1 \mathrm{H}), 7.77(\mathrm{~d}, J=8.0 \mathrm{~Hz}, 1 \mathrm{H}), 7.54(\mathrm{t}, J=7.6 \mathrm{~Hz}, 2 \mathrm{H}), 7.46(\mathrm{~d}, J=8.2$ $\mathrm{Hz}, 1 \mathrm{H}$ ), 7.41-7.35 (multiple peaks, 6H) 7.32-7.27 (multiple peaks, $5 \mathrm{H}) .{ }^{13} \mathrm{C}\left\{{ }^{1} \mathrm{H}\right\} \mathrm{NMR}\left(\mathrm{CDCl}_{3}\right): \delta 149.33$, 145.98, 144.14, 142.37, 135.79, 130.01, 129.31, 128.01, 127.82, 126.20, 125.73, 125.67, 120.68, 49.67. Anal. Calcd for $\mathrm{C}_{22} \mathrm{H}_{17} \mathrm{~N}$ : C, 89.46, H, 5.80, N, 4.74; Found: C, 89.24, H, 5.96, N, 4.63. IR (KBr) $1492 \mathrm{~cm}^{-1}$. Note: Product $\mathbf{6 a}$ is formed in $16 \%$ yield by GC in the absence of Pd catalyst.

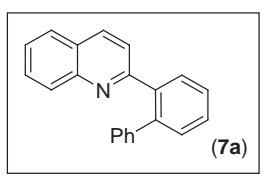

Product 7a. Substrate 7 (200 mg, 0.97 mmol, 1 equiv), [ $\left.\mathrm{Ph}_{2} \mathrm{I}\right] \mathrm{BF}_{4}(428 \mathrm{mg}, 1.16 \mathrm{mmol}, 1.2 \mathrm{equiv})$, and $\mathrm{Pd}(\mathrm{OAc})_{2}(10.9 \mathrm{mg}, 0.054 \mathrm{mmol}, 5 \mathrm{~mol} \%)$ were combined in $\mathrm{AcOH}(8 \mathrm{~mL})$ in a $20 \mathrm{~mL}$ vial. The vial was sealed with a Teflon lined cap, and the reaction was heated at $100^{\circ} \mathrm{C}$ overnight. GC analysis at the completion of the reaction showed 19\% starting material (7), 71\% mono-arylated product (7a) and 10\% of the analogous diarylated product. The reaction mixture was filtered through a plug of Celite and then evaporated to dryness. The resulting oil was dissolved in $\mathrm{CH}_{2} \mathrm{Cl}_{2}$ and extracted with saturated aqueous $\mathrm{NaHCO}_{3}(2 \times 30 \mathrm{~mL})$ and brine $(1 \times 30 \mathrm{~mL})$. The organic extracts were dried over $\mathrm{MgSO}_{4}$ and concentrated under vacuum to afford a yellow oil, which was purified by chromatography on silica gel $\left(R_{\mathrm{f}}=0.22\right.$ in $94 \%$ hexanes $/ 6 \%$ ethyl acetate). The product was obtained as a pale yellow solid (157 $\mathrm{mg}$, $58 \%$ yield); mp $134-138{ }^{\circ} \mathrm{C} .{ }^{1} \mathrm{H}$ NMR $\left(\mathrm{C}_{6} \mathrm{D}_{6}\right): \delta 8.38(\mathrm{~d}, J=8.4 \mathrm{~Hz}, 1 \mathrm{H}), 8.14(\mathrm{dd}, J=7.60,1.45,1 \mathrm{H}), 7.39-7.34$ $(\mathrm{m}, 2 \mathrm{H}), 7.31-7.28(\mathrm{~m}, 2 \mathrm{H}), 7.26-7.16$ (multiple peaks, $6 \mathrm{H}), 6.95-6.90(\mathrm{~m}, 2 \mathrm{H}), 6.88-6.86(\mathrm{~m}, 1 \mathrm{H}) .{ }^{13} \mathrm{C}\left\{{ }^{1} \mathrm{H}\right\}$ $\operatorname{NMR}\left(\mathrm{CDCl}_{3}\right): \delta$ 159.60, 147.94, 140.86, 140.46, 139.45, 134.43, 130.62, 130.21, 129.52, 129.26, 129.06, 128.62, $128.04,127.88,127.59,127.18,126.60,126.27,123.13$. HRMS-electrospray $(m / z):\left[\mathrm{M}^{+}-\mathrm{H}\right]$ calcd for $\mathrm{C}_{21} \mathrm{H}_{15} \mathrm{~N}$, 280.1126; found, 280.1127. IR (KBr) 1699, $1589 \mathrm{~cm}^{-1}$.

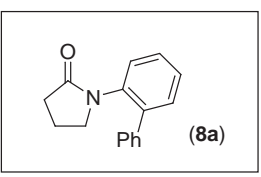

Product 8a. Substrate 8 (152 mg, 0.94 mmol, 1 equiv), [ $\left.\mathrm{Ph}_{2} \mathrm{I}\right] \mathrm{BF}_{4}$ (521 mg, $1.41 \mathrm{mmol}, 1.5$ equiv), $\mathrm{NaHCO}_{3}$ (119 mg, $1.14 \mathrm{mmol}, 1.5$ equiv) and $\mathrm{Pd}(\mathrm{OAc})_{2}(11.9 \mathrm{mg}, 0.053 \mathrm{mmol}, 5 \mathrm{~mol} \%)$ were combined in toluene $(8$ $\mathrm{mL}$ ) in a $20 \mathrm{~mL}$ vial fitted with a Teflon lined cap, and the reaction was stirred at $100^{\circ} \mathrm{C}$ for 24 hours. The reaction mixture was filtered through a plug of Celite and concentrated under vacuum to afford a yellow 
oil, which was purified by chromatography on silica gel $\left(R_{f}=0.1\right.$ in $50 \%$ ethyl acetate $/ 50 \%$ hexanes). The product was obtained as an orange oil $\left(170 \mathrm{mg}, 75 \%\right.$ yield). ${ }^{1} \mathrm{H} \mathrm{NMR}\left(\mathrm{CDCl}_{3}\right): \delta 7.44-7.35$ (multiple peaks, $6 \mathrm{H}), 7.34-7.33(\mathrm{~m}, 2 \mathrm{H}), 7.32(\mathrm{t}, J=1.7 \mathrm{~Hz}, 1 \mathrm{H}), 3.21(\mathrm{t}, J=7.0 \mathrm{~Hz}, 2 \mathrm{H}), 2.43(\mathrm{t}, J=8.1 \mathrm{~Hz}, 2 \mathrm{H}), 1.90-1.83(\mathrm{~m}$, $2 \mathrm{H}) .{ }^{13} \mathrm{C}\left\{{ }^{1} \mathrm{H}\right\}$ NMR (d6-acetone): $\delta 174.18,140.09,140.03,137.60,130.95,129.13,128.78,128.59,128.44$, 127.71, 127.59, 49.65, 31.06, 18.99. Anal. Calcd for $\mathrm{C}_{16} \mathrm{H}_{15} \mathrm{NO}$ : C, 80.98, H, 6.37, N, 5.90; Found: C, 80.67, H, 6.46, N, 5.67. IR (thin film) 1715, $1377 \mathrm{~cm}^{-1}$.

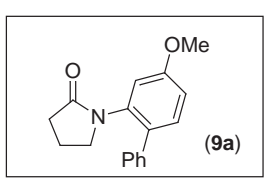

Product 9a. Substrate 9 (180 mg, 0.94 mmol, 1 equiv), [ $\left.\mathrm{Ph}_{2} \mathrm{I}\right] \mathrm{BF}_{4}\left(692 \mathrm{mg}, 1.88 \mathrm{mmol}, 2\right.$ equiv), $\mathrm{Pd}(\mathrm{OAc})_{2}$ (10.5 mg, $0.047 \mathrm{mmol}, 5 \mathrm{~mol} \%$ ) and $\mathrm{NaHCO}_{3}$ (158 mg, $1.88 \mathrm{mmol}, 2$ equiv) were combined in toluene (8 $\mathrm{mL}$ ) in a $20 \mathrm{~mL}$ vial. The vial was sealed with a Teflon lined cap and the reaction was heated at $100^{\circ} \mathrm{C}$ for 12 hours. The reaction mixture was evaporated to dryness, and the residue was redissolved in $\mathrm{CH}_{2} \mathrm{Cl}_{2}$ and filtered through a plug of Celite. The solution was concentrated to afford a yellow oil, which was purified by chromatography on silica gel $\left(\mathrm{R}_{\mathrm{f}}=0.25\right.$ in $70 \%$ ethyl acetate $/ 30 \%$ hexanes). The product was obtained as a yellow solid (211 mg, 84\% yield); mp 61-64 ${ }^{\circ} \mathrm{C} .{ }^{1} \mathrm{H}$ NMR $\left(\mathrm{C}_{6} \mathrm{D}_{6}\right): \delta 7.41-7.39(\mathrm{~m}, 2 \mathrm{H}), 7.18-7.16$ $(\mathrm{m}, 1 \mathrm{H}), 7.14-7.05$ (multiple peaks, $4 \mathrm{H}), 6.73(\mathrm{dd}, J=8.5,2.6 \mathrm{~Hz}, 1 \mathrm{H}), 3.30(\mathrm{~s}, 3 \mathrm{H}), 2.78(\mathrm{t}, J=6.9 \mathrm{~Hz}, 2 \mathrm{H})$, $2.03(\mathrm{t}, J=8.0 \mathrm{~Hz}, 2 \mathrm{H}), 1.19-1.12(\mathrm{~m}, 2 \mathrm{H}) .{ }^{13} \mathrm{C}\{\mathrm{H}\} \mathrm{NMR}\left(\mathrm{CDCl}_{3}\right): \delta 175.15,159.10,138.41,136.62,131.46$, 131.09, 127.92, 127.89, 126.74, 113.70, 112.89, 54.95, 49.66, 30.74, 18.46. HRMS-electrospray $(\mathrm{m} / \mathrm{z}):\left[\mathrm{M}^{+}+\mathrm{Na}\right]$ calcd for $\mathrm{C}_{17} \mathrm{H}_{17} \mathrm{NO}_{2}$, 290.1157; found, 290.1167. IR (KBr) 1687, $1609 \mathrm{~cm}^{-1}$.

The regioselectivity of this reaction could not be definitively determined from the ${ }^{1} \mathrm{H}$ NMR spectrum of 9a due to overlapping aromatic resonances. As a result, a deuterated version of this product was prepared by reaction of 9 with $\left[\mathrm{Mes}-\mathrm{I}-\mathrm{C}_{6} \mathrm{D}_{5}\right] \mathrm{BF}_{4}$ under analogous conditions to those described above. The ${ }^{1} \mathrm{H}$ NMR data for the deuterated product (9a- $\left.d_{5}\right)$ was as follows: ${ }^{1} \mathrm{H}$ NMR ( $d_{6}$-acetone): $\delta 7.31$ $(\mathrm{d}, J=8.5 \mathrm{~Hz}, 1 \mathrm{H}), 6.98(\mathrm{dd}, J=8.5,2.6 \mathrm{~Hz}, 1 \mathrm{H}), 6.92(\mathrm{~d}, J=2.6 \mathrm{~Hz}, 1 \mathrm{H}), 3.84(\mathrm{~s}, 3 \mathrm{H}), 3.26(\mathrm{t}, J=6.9 \mathrm{~Hz}, 2 \mathrm{H})$, $2.26(\mathrm{t}, J=8.0 \mathrm{~Hz}, 2 \mathrm{H}), 1.91-1.84(\mathrm{~m}, 2 \mathrm{H})$.

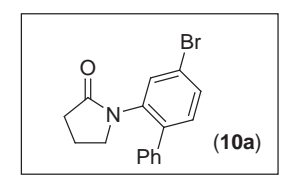

Product 10a. Substrate 10 (180 mg, $0.75 \mathrm{mmol}, 1$ equiv), [ $\left.\mathrm{Ph}_{2} \mathrm{I}\right] \mathrm{BF}_{4}(689 \mathrm{mg}, 1.87 \mathrm{mmol}, 2.5$ equiv), and $\mathrm{Pd}(\mathrm{OAc})_{2}(8.4 \mathrm{mg}, 0.038 \mathrm{mmol}, 5 \mathrm{~mol} \%)$ were combined in toluene $(6.25 \mathrm{~mL})$ in a $20 \mathrm{~mL}$ vial. The vial was sealed with a Teflon lined cap and the reaction was heated at $100^{\circ} \mathrm{C}$ for 12 hours. The reaction mixture 
was filtered through a plug of Celite and then evaporated to dryness. The resulting oil was dissolved in methylene chloride and extracted with saturated aqueous $\mathrm{NaHCO}_{3}(2 \times 30 \mathrm{~mL})$ and brine $(1 \times 30 \mathrm{~mL})$. The organic layer was dried over $\mathrm{MgSO}_{4}$, filtered, and concentrated to afford an orange oil, which was purified by chromatography on silica gel $\left(\mathrm{R}_{\mathrm{f}}=0.23\right.$ in $96 \% \mathrm{CH}_{2} \mathrm{Cl}_{2} / 4 \%$ ethyl acetate). The product was obtained as an orange-brown solid (180 mg, 78\% yield); mp 116-118 ${ }^{\circ} \mathrm{C} .{ }^{1} \mathrm{H}$ NMR $\left(\mathrm{C}_{6} \mathrm{D}_{6}\right)$ : $\delta 7.52(\mathrm{~s}, 1 \mathrm{H})$, $7.23(\mathrm{~d}, J=7.3 \mathrm{~Hz}, 2 \mathrm{H}), 7.13-7.06$ (multiple peaks, 4H), $6.79(\mathrm{~d}, J=8.1 \mathrm{~Hz}, 1 \mathrm{H}), 2.59(\mathrm{t}, J=6.8 \mathrm{~Hz}, 2 \mathrm{H}), 1.93$ $(\mathrm{t}, J=8.0 \mathrm{~Hz}, 2 \mathrm{H}), 1.13-1.06(\mathrm{~m}, 2 \mathrm{H}) .{ }^{13} \mathrm{C}\left\{{ }^{1} \mathrm{H}\right\} \mathrm{NMR}\left(\mathrm{CDCl}_{3}\right): \delta 175.39,138.49,137.84,137.38,131.89,131.26$, 130.90, 128.39, 127.93, 127.75, 121.44, 49.77, 30.85, 18.79. Anal. Calcd for $\mathrm{C}_{16} \mathrm{H}_{14} \mathrm{BrNO}$ : C, 60.78, H, 4.46, N, 4.43; Found: C, 61.08, H, 4.66, N, 4.19. IR (KBr) 1697, $1413 \mathrm{~cm}^{-1}$.

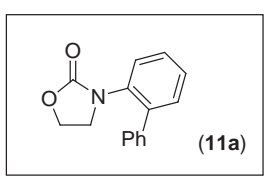

Product 11a. Substrate 11 (150 mg, $0.92 \mathrm{mmol}, 1$ equiv), [ $\left.\mathrm{Ph}_{2} \mathrm{I}\right] \mathrm{BF}_{4}$ (676 mg, $1.84 \mathrm{mmol}, 2$ equiv), $\mathrm{Pd}(\mathrm{OAc})_{2}$ (10.2 mg, $0.046 \mathrm{mmol}, 5 \mathrm{~mol} \%)$ and $\mathrm{NaHCO}_{3}$ (155 mg, $1.84 \mathrm{mmol}, 2$ equiv) were combined in benzene (8 $\mathrm{mL}$ ) in a $20 \mathrm{~mL}$ vial. The vial was sealed with a Teflon lined cap and the reaction was heated at $100^{\circ} \mathrm{C}$ for 12 hours. The reaction mixture was filtered through a plug of Celite and then evaporated to dryness. The resulting oil was dissolved in $\mathrm{CH}_{2} \mathrm{Cl}_{2}$ and extracted with saturated aqueous $\mathrm{NaHCO}_{3}(2 \times 30 \mathrm{~mL})$ and brine $(1 \times 30 \mathrm{~mL})$. The organic layer was dried over $\mathrm{MgSO}_{4}$, filtered, and concentrated to afford an orange oil, which was purified by chromatography on silica gel $\left(\mathrm{R}_{\mathrm{f}}=0.23\right.$ in $97.5 \% \mathrm{CH}_{2} \mathrm{Cl}_{2} / 2.5 \%$ ethyl acetate). The product was obtained as a yellow solid (182 mg, 83\% yield); mp 107-109 ${ }^{\circ} \mathrm{C} .{ }^{1} \mathrm{H}$ NMR $\left(\mathrm{C}_{6} \mathrm{D}_{6}\right): \delta 7.38$ $(\mathrm{dd}, J=7.8,1.2 \mathrm{~Hz}, 1 \mathrm{H}), 7.32-7.30(\mathrm{~m}, 2 \mathrm{H}), 7.14-7.12(\mathrm{~m}, 1 \mathrm{H})$, 7.10-7.06 (multiple peaks, 3H), 7.05-6.99 (m, 2H) $3.24(\mathrm{dd}, J=8.6,7.2 \mathrm{~Hz}, 2 \mathrm{H}), 2.55(\mathrm{dd}, J=8.5,7.2 \mathrm{~Hz}, 2 \mathrm{H}) .{ }^{13} \mathrm{C}\left\{{ }^{1} \mathrm{H}\right\} \mathrm{NMR}\left(\mathrm{CDCl}_{3}\right): \delta$ 157.78, 139.62, $139.00,135.08,131.10,128.89,128.87,128.58,128.41,128.25,127.99,62.43,47.13$. Anal. Calcd for $\mathrm{C}_{15} \mathrm{H}_{13} \mathrm{NO}_{2}$ : C, 75.30, H, 5.48, N, 5.85; Found: C, 75.50, H, 5.66, N, 5.68. IR (KBr) 1740, $1483 \mathrm{~cm}^{-1}$.

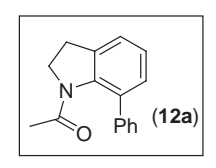

Product 12a. Substrate 12 (150 mg, $0.93 \mathrm{mmol}, 1$ equiv), [ $\left.\mathrm{Ph}_{2} \mathrm{I}\right] \mathrm{BF}_{4}(685 \mathrm{mg}, 1.86 \mathrm{mmol}, 2$ equiv), and $\mathrm{Pd}(\mathrm{OAc})_{2}(10.4 \mathrm{mg}, 0.047 \mathrm{mmol}, 5 \mathrm{~mol} \%)$ were combined in $\mathrm{AcOH}(5 \mathrm{~mL})$ and $\mathrm{Ac}_{2} \mathrm{O}(5 \mathrm{~mL})$ in a $20 \mathrm{~mL}$ vial. The vial was sealed with a Teflon lined cap, and the reaction was heated at $100^{\circ} \mathrm{C}$ overnight. GC analysis at the completion of the reaction showed $29 \%$ starting material (12) and $71 \%$ of the monoarylated product (12a). Notably, attempts to optimize the reaction conditions did not lead to further conversion with this substrate. The reaction mixture was evaporated to dryness, and the remaining solid 
residue was taken up in $\mathrm{MeOH}(20 \mathrm{~mL})$ and filtered through a plug of Celite. The methanol was removed under vacuum and the solids were taken up in $\mathrm{CH}_{2} \mathrm{Cl}_{2}$ and extracted with saturated aqueous $\mathrm{NaHCO}_{3}(3$ x $30 \mathrm{~mL}$ ). The organic extracts were concentrated under vacuum to afford a red oil, which was purified by chromatography on silica gel $\left(R_{\mathrm{f}}=0.2\right.$ in $70 \%$ hexanes $/ 30 \%$ ethyl acetate). The product was obtained as pale yellow solid (108 $\mathrm{mg}, 49 \%$ yield); $\mathrm{mp} 117-119{ }^{\circ} \mathrm{C} .{ }^{1} \mathrm{H}$ NMR ( $d_{6}$-acetone): $\delta$ 7.52-7.14 (multiple peaks, $8 \mathrm{H}), 4.23(\mathrm{t}, J=7.2 \mathrm{~Hz}, 2 \mathrm{H}), 3.02(\mathrm{t}, J=7.2 \mathrm{~Hz}, 2 \mathrm{H}), 1.50$ (br s, $3 \mathrm{H}) .{ }^{13} \mathrm{C}\left\{{ }^{1} \mathrm{H}\right\}$ NMR (d -acetone): $\delta 141.58$, $129.77,128.16,127.78,126.02,124.67,51.15,22.89$. (The ${ }^{13} \mathrm{C}$ NMR peaks of 12a are broad and several are missing, presumably as a result of fluxional motion of the amide.) Anal. Calcd for $\mathrm{C}_{16} \mathrm{H}_{15} \mathrm{NO}$ : C, 80.98, $\mathrm{H}$, 6.37, N, 5.90; Found: C, 80.89, H, 6.52, N, 5.58. IR (KBr) $1648 \mathrm{~cm}^{-1}$.

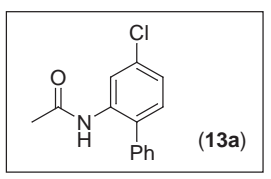

Product 13a. Substrate 13 (250 mg, $1.47 \mathrm{mmol}, 1$ equiv), [ $\left.\mathrm{Ph}_{2} \mathrm{I}\right] \mathrm{BF}_{4}$ (1.08 g, $2.95 \mathrm{mmol}, 2$ equiv), and $\mathrm{Pd}(\mathrm{OAc})_{2}(16.5 \mathrm{mg}, 0.074 \mathrm{mmol}, 5 \mathrm{~mol} \%)$ were combined in benzene $(12 \mathrm{~mL})$ in a $20 \mathrm{~mL}$ vial. The vial was sealed with a Teflon lined cap and the reaction was heated at $100^{\circ} \mathrm{C}$ for 12 hours. The reaction mixture was filtered through a plug of Celite and then evaporated to dryness. The resulting oil was dissolved in $\mathrm{CH}_{2} \mathrm{Cl}_{2}$ and extracted with saturated aqueous $\mathrm{NaHCO}_{3}(2 \times 30 \mathrm{~mL})$ and brine $(1 \times 30 \mathrm{~mL})$. The organic layer was dried over $\mathrm{MgSO}_{4}$, filtered, and concentrated to afford an orange oil, which was purified by chromatography on silica gel ( $R_{\mathrm{f}}=0.28$ in $55 \%$ diethyl ether $/ 45 \%$ hexanes). The product was obtained as an orange-brown solid (240 mg, 67\% yield); mp 125-126 ${ }^{\circ} \mathrm{C} .{ }^{1} \mathrm{H}$ NMR $\left(\mathrm{C}_{6} \mathrm{D}_{6}\right): \delta 9.02(\mathrm{~s}, 1 \mathrm{H}), 7.10-7.05$ (multiple peaks, 3H), 6.97-6.95 (m, 2H), $6.91(\mathrm{dd}, J=8.2,2.2 \mathrm{~Hz}, 1 \mathrm{H}), 6.75(\mathrm{~d}, J=8.2 \mathrm{~Hz}, 1 \mathrm{H}), 6.64(\mathrm{~s}, 1 \mathrm{H})$, $1.25(\mathrm{~s}, 3 \mathrm{H}) .{ }^{13} \mathrm{C}\left\{{ }^{1} \mathrm{H}\right\} \mathrm{NMR}\left(\mathrm{CDCl}_{3}\right): \delta 167.96,136.65,135.27,133.40,130.55,130.19,128.82,128.66,127.88$, 123.94, 121.24, 24.04. Anal. Calcd for $\mathrm{C}_{14} \mathrm{H}_{12}$ ClNO: C, 68.44, H, 4.92, N, 5.70; Found: C, 68.38, H, 4.99, N, 5.47. IR (KBr) 3224, 3026, 1648, $1532 \mathrm{~cm}^{-1}$.

The regioselectivity of this reaction could not be definitively assigned from the ${ }^{1} \mathrm{H}$ NMR spectrum of 13a due to overlapping aromatic resonances. As a result, a deuterated version of this product was prepared by reaction of $\mathbf{1 3}$ with [Mes-I- $\left.\mathrm{C}_{6} \mathrm{D}_{5}\right] \mathrm{BF}_{4}$ under analogous conditions to those described above. The ${ }^{1} \mathrm{H}$ NMR data for the deuterated product (13a- $\left.\boldsymbol{d}_{5}\right)$ was as follows: ${ }^{1} \mathrm{H}$ NMR $\left(\mathrm{C}_{6} \mathrm{D}_{6}\right): \delta 9.02$ (br. s, $1 \mathrm{H}), 6.92(\mathrm{dd}, J=8.2,2.1 \mathrm{~Hz}, 1 \mathrm{H}), 6.75(\mathrm{~d}, J=8.2 \mathrm{~Hz}, 1 \mathrm{H}), 6.64$ (br. s, $1 \mathrm{H}), 1.25$ (s, 3H). 


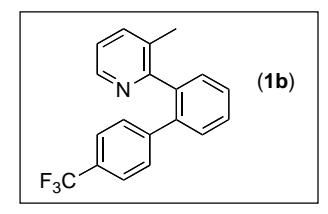

Product 1b. Substrate 1 (150 mg, 0.89 mmol, 1 equiv), [Mes-I- $p-\mathrm{CF}_{3} \mathrm{C}_{6} \mathrm{H}_{5}$ ] BF 4 (466 mg, 0.98 mmol, 1.1 equiv) and $\mathrm{Pd}(\mathrm{OAc})_{2}(10 \mathrm{mg}, 0.044 \mathrm{mmol}, 5 \mathrm{~mol} \%)$ were combined in acetic acid $(8 \mathrm{~mL})$ in a $20 \mathrm{~mL}$ vial. The vial was sealed with a Teflon lined cap, and the reaction was stirred at $100^{\circ} \mathrm{C}$ for 12 hours. The reaction mixture was filtered through a plug of glass wool and concentrated under vacuum. The resulting oil was dissolved in $\mathrm{CH}_{2} \mathrm{Cl}_{2}$ and extracted with saturated aqueous $\mathrm{NaHCO}_{3}(1 \times 30 \mathrm{~mL})$. The organic layer was dried over $\mathrm{MgSO}_{4}$, filtered, and concentrated to afford an orange oil, which was purified by chromatography on silica gel $\left(R_{\mathrm{f}}=0.25\right.$ in $75 \%$ hexanes $/ 25 \%$ ethyl acetate). The product was obtained as a yellow oil (242 mg, 87\% yield). ${ }^{1} \mathrm{H}$ NMR ( $d_{6}$-acetone): $\delta 8.42$ (d, $\left.J=4.2 \mathrm{~Hz}, 1 \mathrm{H}\right), 7.57-7.53$ (multiple peaks, $5 \mathrm{H}), 7.46-7.40$ (multiple peaks, $2 \mathrm{H}), 7.35(\mathrm{~d}, J=8.4 \mathrm{~Hz}, 2 \mathrm{H}), 7.18(\mathrm{dd}, J=8.0 \mathrm{~Hz}, 7.6 \mathrm{~Hz}, 1 \mathrm{H}) .{ }^{13} \mathrm{C}\left\{{ }^{1} \mathrm{H}\right\} \mathrm{NMR}$ (d6-acetone): $\delta 159.83,147.84,146.27,140.87,140.13,138.42,132.21,131.06,130.76,130.59,129.34,129.08$ (d, $J=32 \mathrm{~Hz}), 128.99,125.59(\mathrm{q}, J=4 \mathrm{~Hz}), 124.43(\mathrm{q}, 270 \mathrm{~Hz}), 123.39$, 19.08. Anal. Calcd for $\mathrm{C}_{18} \mathrm{H}_{14} \mathrm{FN}: \mathrm{C}$, 72.83, H, 4.50, N, 4.47; Found: C, 72.53, H, 4.60, N, 4.36.

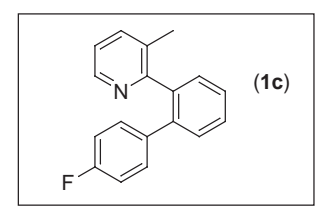

Product 1c. Substrate 1 (153 mg, 0.91 mmol, 1 equiv), [Mes-I- $\left.p-\mathrm{FC}_{6} \mathrm{H}_{5}\right]_{\mathrm{BF}}$ (446 mg, 1.04 mmol, 1.15 equiv) and $\mathrm{Pd}(\mathrm{OAc})_{2}(10.1 \mathrm{mg}, 0.043 \mathrm{mmol}, 5 \mathrm{~mol} \%)$ were combined in acetic acid $(8 \mathrm{~mL})$ in a $20 \mathrm{~mL}$ vial. The vial was sealed with a Teflon lined cap, and the reaction was stirred at $100^{\circ} \mathrm{C}$ for 12 hours. The reaction mixture was filtered through a plug of glass wool and concentrated under vacuum. The resulting oil was dissolved in $\mathrm{CH}_{2} \mathrm{Cl}_{2}$ and extracted with saturated aqueous $\mathrm{NaHCO}_{3}(1 \times 30 \mathrm{~mL})$. The organic layer was dried over $\mathrm{MgSO}_{4}$, filtered, and concentrated to afford an orange oil, which was purified by chromatography on silica gel $\left(\mathrm{R}_{\mathrm{f}}=0.3\right.$ in $75 \%$ hexanes $/ 25 \%$ ethyl acetate). The product was obtained as a yellow solid (210 mg, 88\% yield); mp 135-137 ${ }^{\circ} \mathrm{C} .{ }^{1} \mathrm{H}$ NMR ( $d_{6}$-acetone): $\delta 8.43(\mathrm{~d}, J=4.0 \mathrm{~Hz}, 1 \mathrm{H}), 7.57-7.32$ (multiple peaks, 5H), 7.22-7.12 (multiple peaks, 3H), 6.97-6.93 (m, 2H), $1.77(\mathrm{~s}, 3 \mathrm{H}) .{ }^{13} \mathrm{C}\left\{{ }^{1} \mathrm{H}\right\}$ NMR $\left(d_{6^{-}}\right.$ acetone): $\delta 162.60\left(\mathrm{~d},{ }^{1} J_{\mathrm{CF}}=243 \mathrm{~Hz}\right), 160.15,147.34,140.76,140.35,138.29\left(\mathrm{~d},{ }^{4} J_{\mathrm{CF}}=3.0 \mathrm{~Hz}\right), 138.12,131.99$, $131.82\left(\mathrm{~d},{ }^{3} J_{\mathrm{CF}}=7.6 \mathrm{~Hz}\right), 130.79,130.30,129.07,128.16,123.10,115.35\left(\mathrm{~d},{ }^{2} J_{\mathrm{CF}}=21 \mathrm{~Hz}\right), 18.91$. Anal. Calcd for $\mathrm{C}_{18} \mathrm{H}_{14} \mathrm{FN}$ : C, 82.11, H, 5.36, N, 5.32; Found: C, 81.86, H, 5.52, N, 5.15. IR (KBr) $1482 \mathrm{~cm}^{-1}$. 


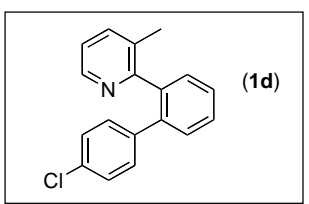

Product 1d. Substrate 1 (150 mg, 0.89 mmol, 1 equiv), [Mes-I- $p-\mathrm{ClC}_{6} \mathrm{H}_{5}$ ] $\mathrm{BF}_{4}$ (453 mg, 1.02 mmol, 1.15 equiv) and $\mathrm{Pd}(\mathrm{OAc})_{2}(10 \mathrm{mg}, 0.044 \mathrm{mmol}, 5 \mathrm{~mol} \%)$ were combined in acetic acid $(8 \mathrm{~mL})$ in a $20 \mathrm{~mL}$ vial. The vial was sealed with a Teflon lined cap, and the reaction was stirred at $100^{\circ} \mathrm{C}$ for 12 hours. The reaction mixture was filtered through a plug of glass wool and concentrated under vacuum. The resulting oil was dissolved in $\mathrm{CH}_{2} \mathrm{Cl}_{2}$ and extracted with saturated aqueous $\mathrm{NaHCO}_{3}(1 \times 30 \mathrm{~mL})$. The organic layer was dried over $\mathrm{MgSO}_{4}$, filtered, and concentrated to afford an orange oil, which was purified by chromatography on silica gel $\left(\mathrm{R}_{\mathrm{f}}=0.25\right.$ in $75 \%$ hexanes $/ 25 \%$ ethyl acetate). The product was obtained as a yellow solid (205 mg, 83\% yield); mp 106-107 ${ }^{\circ} \mathrm{C}$. ${ }^{1} \mathrm{H}$ NMR (d6-acetone): $\delta 8.42(\mathrm{dd}, J=4.8,1.2 \mathrm{~Hz}, 1 \mathrm{H})$, 7.55-7.46 (multiple peaks, 3H), $7.43(\mathrm{dt}, J=7.5,0.8 \mathrm{~Hz}, 1 \mathrm{H}), 7.38-7.36(\mathrm{~m}, 1 \mathrm{H}), 7.21-7.12$ (multiple peaks, $5 \mathrm{H}), 1.79(\mathrm{~s}, 3 \mathrm{H}) .{ }^{13} \mathrm{C}\left\{{ }^{1} \mathrm{H}\right\} \mathrm{NMR}\left(d_{6}\right.$-acetone): $\delta$ 160.11, 147.48, 140.84, 140.82, 140.25, 138.31, 133.25, 132.12, 131.71, 130.95, 130.39, 129.25, 128.81, 128.53, 123.27, 19.07. Anal. Calcd for $\mathrm{C}_{18} \mathrm{H}_{14} \mathrm{FN}$ : C, 77.28, H, 5.04, N, 5.01; Found: C, 77.59, H, 4.91, N, 4.63. IR (KBr) 1477, $1449 \mathrm{~cm}^{-1}$.

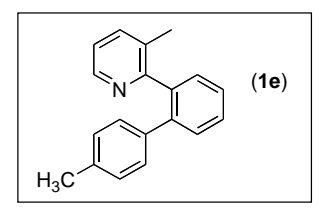

Product 1e. Substrate 1 (150 mg, 0.89 mmol, 1 equiv), [Mes-I- $p-\mathrm{CH}_{3} \mathrm{C}_{6} \mathrm{H}_{5}$ ] $\mathrm{BF}_{4}$ (432 mg, $1.02 \mathrm{mmol}, 1.15$ equiv) and $\mathrm{Pd}(\mathrm{OAc})_{2}(10 \mathrm{mg}, 0.044 \mathrm{mmol}, 5 \mathrm{~mol} \%)$ were combined in acetic acid $(8 \mathrm{~mL})$ in a $20 \mathrm{~mL}$ vial. The vial was sealed with a Teflon lined cap, and the reaction was stirred at $100^{\circ} \mathrm{C}$ for 12 hours. The reaction mixture was filtered through a plug of glass wool and concentrated under vacuum. The resulting oil was dissolved in $\mathrm{CH}_{2} \mathrm{Cl}_{2}$ and extracted with saturated aqueous $\mathrm{NaHCO}_{3}(1 \times 30 \mathrm{~mL})$. The organic layer was dried over $\mathrm{MgSO}_{4}$, filtered, and concentrated to afford an orange oil, which was purified by chromatography on silica gel $\left(\mathrm{R}_{\mathrm{f}}=0.25\right.$ in $80 \%$ hexanes $/ 20 \%$ ethyl acetate). The product was obtained as a yellow solid (193 mg, 84\% yield); mp 59-62 ${ }^{\circ} \mathrm{C} .{ }^{1} \mathrm{H}$ NMR ( $d_{6}$-acetone): $\delta 8.45$ (d, $\left.J=4.4 \mathrm{~Hz}, 1 \mathrm{H}\right), 7.50-7.43$ (multiple peaks, 3H), 7.39-7.33 (multiple peaks, $2 \mathrm{H}$ ), $7.15(\mathrm{t}, J=7.6 \mathrm{~Hz}, 1 \mathrm{H}), 7.04-6.98$ (multiple peaks, $4 \mathrm{H}$ ), $2.23(\mathrm{~s}, 3 \mathrm{H}), 1.74(\mathrm{~s}, 3 \mathrm{H}) .{ }^{13} \mathrm{C}\{1 \mathrm{H}\}$ NMR (d6-acetone): $\delta 159.68,146.39,140.49,139.81,138.29,137.15,136.14$, 131.16, 129.95, 129.43, 128.98, 128.46, 128.13, 126.91, 122.12. Anal. Calcd for $\mathrm{C}_{18} \mathrm{H}_{14} \mathrm{FN}$ : C, 87.99, H, 6.61, N, 5.40; Found: C, 87.73, H, 6.45, N, 5.11. IR (KBr) $1449 \mathrm{~cm}^{-1}$. 


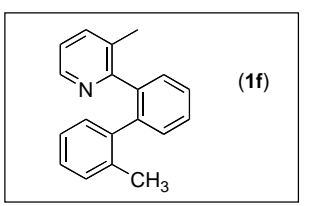

Product 1f. Substrate 1 (150 mg, 0.89 mmol, 1 equiv), [Mes-I- $p-\mathrm{CH}_{3} \mathrm{C}_{6} \mathrm{H}_{5}$ ] $\mathrm{BF}_{4}$ (489 mg, $1.15 \mathrm{mmol}, 1.3$ equiv) and $\mathrm{Pd}(\mathrm{OAc})_{2}(10 \mathrm{mg}, 0.044 \mathrm{mmol}, 5 \mathrm{~mol} \%)$ were combined in acetic acid $(8 \mathrm{~mL})$ in a $20 \mathrm{~mL}$ vial. The vial was sealed with a Teflon lined cap, and the reaction was stirred at $100^{\circ} \mathrm{C}$ for 12 hours. The reaction mixture was filtered through a plug of glass wool and concentrated under vacuum. The resulting oil was dissolved in $\mathrm{CH}_{2} \mathrm{Cl}_{2}$ and extracted with saturated aqueous $\mathrm{NaHCO}_{3}(1 \times 30 \mathrm{~mL})$. The organic layer was dried over $\mathrm{MgSO}_{4}$, filtered, and concentrated to afford an orange oil, which was purified by chromatography on silica gel $\left(R_{\mathrm{f}}=0.25 \mathrm{in} 80 \%\right.$ hexanes $/ 20 \%$ ethyl acetate). The product was obtained as a white solid (165 mg, 72\% yield); mp 73-77 ${ }^{\circ} \mathrm{C}$. ${ }^{1} \mathrm{H}$ NMR (d6-acetone): $\delta 8.30(\mathrm{~d}, J=3.6 \mathrm{~Hz}, 1 \mathrm{H}), 7.48-7.44$ (multiple peaks, 2H), 7.39-7.36 (multiple peaks, 2H), 7.32-7.30 (m, 1H), 7.10-7.03 (multiple peaks, 3H), 6.96-6.92 (multiple peaks, $2 \mathrm{H}), 2.16(\mathrm{~s}, 3 \mathrm{H}), 1.95(\mathrm{~s}, 3 \mathrm{H}) .{ }^{13} \mathrm{C}\left\{{ }^{1} \mathrm{H}\right\} \mathrm{NMR}$ (d6-acetone): $\delta 160.12,147.01,141.58$ (br), 141.42, 137.95, 136.67 (br), 131.97, 131.13, 130.67, 130.63, 128.35, 127.81, 125.53, 122.81, 20.74, 19.34. (Several of the ${ }^{13} \mathrm{C}$ NMR peaks of $\mathbf{1 h}$ are broad and three are missing - this is believed to be the result of fluxional motion about the aryl-aryl bonds.) Anal. Calcd for $\mathrm{C}_{18} \mathrm{H}_{14} \mathrm{FN}$ : C, 87.99, H, 6.61, N, 5.40; Found: C, 88.09, H, 6.51, N, 5.24. IR (KBr) $1418 \mathrm{~cm}^{-1}$.

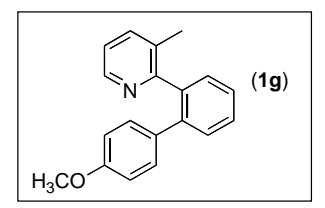

Product 1g. Substrate 1 (150 mg, 0.89 mmol, 1 equiv), [Mes-I- $p-\mathrm{MeOC}_{6} \mathrm{H}_{5}$ ] $\mathrm{BF}_{4}(449 \mathrm{mg}, 1.02 \mathrm{mmol}, 1.1$ equiv) and $\mathrm{Pd}(\mathrm{OAc})_{2}(10 \mathrm{mg}, 0.044 \mathrm{mmol}, 5 \mathrm{~mol} \%)$ were combined in acetic acid $(8 \mathrm{~mL})$ in a $20 \mathrm{~mL}$ vial. The vial was sealed with a Teflon lined cap, and the reaction was stirred at $120^{\circ} \mathrm{C}$ for 12 hours. The reaction mixture was filtered through a plug of glass wool and concentrated under vacuum. The resulting oil was dissolved in $\mathrm{CH}_{2} \mathrm{Cl}_{2}$ and extracted with saturated aqueous $\mathrm{NaHCO}_{3}(1 \times 30 \mathrm{~mL})$. The organic layer was dried over $\mathrm{MgSO}_{4}$, filtered, and concentrated to afford an orange oil, which was purified by chromatography on silica gel $\left(R_{\mathrm{f}}=0.20\right.$ in $80 \%$ hexanes $/ 20 \%$ ethyl acetate). The product was obtained as a clear oil (197 mg, 81\% yield); ${ }^{1} \mathrm{H}$ NMR ( $d_{6}$-acetone): $\delta 8.42(\mathrm{~d}, J=4.4 \mathrm{~Hz}, 1 \mathrm{H}), 7.46-7.28$ (multiple peaks, $5 \mathrm{H}), 7.14-7.11(\mathrm{~m}, 1 \mathrm{H}), 7.02(\mathrm{~d}, J=8.4 \mathrm{~Hz}, 2 \mathrm{H}), 6.70(\mathrm{~d}, J=8.4 \mathrm{~Hz}, 2 \mathrm{H}), 3.68(\mathrm{~s}, 3 \mathrm{H}), 1.70(\mathrm{~s}, 3 \mathrm{H}) .{ }^{13} \mathrm{C}\left\{{ }^{1} \mathrm{H}\right\}$ NMR ( $d_{6}$-acetone): $\delta 159.73,158.68,146.42,140.22,139.73,137.18,133.40,131.17,130.17,129.94,129.33$, $128.13,126.68,122.12,113.22,54.49,18.09$. HRMS (electrospray) $\left[\mathrm{M}^{+}\right]$calcd for $\mathrm{C}_{19} \mathrm{H}_{19} \mathrm{NO}, 275.1310$; found, 275.1303. IR (KBr) 1609, $1516 \mathrm{~cm}^{-1}$. 
Reaction of 1 with Ph-I. Substrate 1 (15.0 mg, 0.09 mmol, 1 equiv), Ph-I (21.7 mg, 0.11 mmol, 1.20 equiv), and $\mathrm{Pd}(\mathrm{OAc})_{2}(1.00 \mathrm{mg}, 0.004 \mathrm{mmol}, 5 \mathrm{~mol} \%)$ were combined in $\mathrm{AcOH}(1.04 \mathrm{~mL})$ in a $2 \mathrm{~mL}$ vial equipped with a small magnetic stir bar. The vial was sealed with a Teflon-lined cap and heated at $100^{\circ} \mathrm{C}$ for $12 \mathrm{hr}$. The reaction was cooled to room temperature and analyzed by gas chromatography, which showed only starting material and $\mathrm{Ph}-\mathrm{I}$ with $<1 \%$ of product 1 a.

Reaction of 1 with Ph-OTf. Substrate 1 (15.0 mg, 0.09 mmol, 1 equiv), Ph-OTf (24.1 mg, 0.11 mmol, 1.20 equiv), and $\mathrm{Pd}(\mathrm{OAc})_{2}(1.00 \mathrm{mg}, 0.0044 \mathrm{mmol}, 5 \mathrm{~mol} \%)$ were combined in $\mathrm{AcOH}(1.04 \mathrm{~mL})$ in a $2 \mathrm{~mL}$ vial equipped with a small magnetic stir bar. The vial was sealed with a Teflon-lined cap and heated at $100^{\circ} \mathrm{C}$ for $12 \mathrm{hr}$. The reaction was cooled to room temperature and analyzed by gas chromatography, which showed only starting material (1) and Ph-OTf with $<1 \%$ of product 1 a.

Reaction of 1 with $\left[\mathrm{Ph}_{2} \mathrm{I}\right] \mathrm{BF}_{4}$ in the Presence of $\mathbf{H g}$. Substrate $\mathbf{1}\left(10.0 \mathrm{mg}, 0.059 \mathrm{mmol}, 1\right.$ equiv), $\left[\mathrm{Ph}_{2} \mathrm{I}\right] \mathrm{BF} 4$ (26.1 mg, $0.071 \mathrm{mmol}, 1.20$ equiv), and $\mathrm{Pd}(\mathrm{OAc})_{2}(0.700 \mathrm{mg}, 0.0031 \mathrm{mmol}, 5 \mathrm{~mol} \%)$ were combined in $\mathrm{AcOH}(0.50 \mathrm{~mL})$ in a $2 \mathrm{~mL}$ vial equipped with a small magnetic stir bar. Metallic $\mathrm{Hg}$ (>500 equiv) was added to the reaction mixture, and the vial was sealed with a Teflon-lined cap and heated at $100^{\circ} \mathrm{C}$ for 12 hr. The reaction was cooled to room temperature and analyzed by gas chromatography, which revealed quantitative conversion to product 1a. SAFETY NOTE: These reactions should be handled with extreme caution, as the reaction of excess $\left[\mathrm{Ph}_{2} \mathrm{I}\right] \mathrm{BF}_{4}$ is known to generate highly toxic phenyl mercury compounds! ${ }^{9}$

Reaction of 1 with $\left[\mathrm{Ph}_{2} \mathrm{I}\right] \mathrm{BF}$ in the Presence of MEHQ. Substrate 1 (10.0 mg, $0.059 \mathrm{mmol}, 1$ equiv), $\left[\mathrm{Ph}_{2} \mathrm{I}\right] \mathrm{BF}_{4}\left(26.1 \mathrm{mg}, 0.071 \mathrm{mmol}, 1.20\right.$ equiv), and $\mathrm{Pd}(\mathrm{OAc})_{2}(0.700 \mathrm{mg}, 0.0031 \mathrm{mmol}, 5 \mathrm{~mol} \%)$ were combined in $\mathrm{AcOH}(0.50 \mathrm{~mL})$ in a $2 \mathrm{~mL}$ vial equipped with a small magnetic stir bar. MEHQ (1.83 mg, $0.015 \mathrm{mmol}, 25 \mathrm{~mol} \%$ ) was added to the reaction mixture, and the vial was sealed with a Teflon-lined cap and heated at $100^{\circ} \mathrm{C}$ for $12 \mathrm{hr}$. The reaction was cooled to room temperature and analyzed by gas chromatography, which revealed quantitative conversion to product 1a.

Reaction of 1 with $\left[\mathrm{Ph}_{2} \mathbf{I}\right] \mathrm{BF}_{4}$ in the Presence of Galvinoxyl. Substrate 1 (10.0mg, $0.059 \mathrm{mmol}, 1$ equiv), $\left[\mathrm{Ph}_{2} \mathrm{I}\right] \mathrm{BF}_{4}$ (26.1 mg, $0.071 \mathrm{mmol}, 1.20$ equiv), and $\mathrm{Pd}(\mathrm{OAc})_{2}(0.700 \mathrm{mg}, 0.0031 \mathrm{mmol}, 5 \mathrm{~mol} \%)$ were combined in $\mathrm{AcOH}(0.50 \mathrm{~mL})$ in a $2 \mathrm{~mL}$ vial equipped with a small magnetic stir bar. Galvinoxyl $(6.23 \mathrm{mg}$, $0.015 \mathrm{mmol}, 25 \mathrm{~mol} \%$ ) was added to the reaction mixture, and the vial was sealed with a Teflon-lined cap and heated at $100^{\circ} \mathrm{C}$ for $12 \mathrm{hr}$. The reaction was cooled to room temperature and analyzed by gas chromatography, which revealed quantitative conversion to product 1a. 


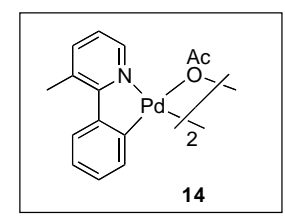

Synthesis of Palladacycle 14. Substrate $1\left(1.07 \mathrm{~g}, 6.30 \mathrm{mmol}, 1.4\right.$ equiv), and $\mathrm{Pd}(\mathrm{OAc})_{2}(1.01 \mathrm{~g}, 4.50 \mathrm{mmol}$, 1 equiv) were combined in $\mathrm{MeOH}(63 \mathrm{~mL})$ in a $200 \mathrm{~mL}$ flask equipped with a magnetic stir bar and stirred at room temperature for $12 \mathrm{hr}$. The reaction mixture was then filtered, and the precipitate was washed with diethyl ether $(100 \mathrm{~mL})$, collected and dried. The product was obtained as a yellow solid (918 $\mathrm{mg}$, $61 \%$ yield). ${ }^{1} \mathrm{H}$ NMR (d $d_{6}$-acetone): $\delta 7.92(\mathrm{~d}, J=5.2 \mathrm{~Hz}, 2 \mathrm{H}), 7.42(\mathrm{~d}, J=7.5 \mathrm{~Hz}, 2 \mathrm{H}), 7.26(\mathrm{~d}, J=7.5 \mathrm{~Hz}, 2 \mathrm{H})$, $6.94(\mathrm{~d}, J=7.4 \mathrm{~Hz}, 2 \mathrm{H}), 6.88-6.78$ (multiple peaks, 4H), $6.53(\mathrm{dd}, J=7.6,2.0 \mathrm{~Hz}, 2 \mathrm{H}), 2.44(\mathrm{~s}, 6 \mathrm{H}), 2.09$ (s, 6H). Anal. Calcd for $\mathrm{C}_{28} \mathrm{H}_{26} \mathrm{~N}_{2} \mathrm{O}_{4} \mathrm{Pd}_{2}$ : C, 50.39, $\mathrm{H}, 3.93, \mathrm{~N}, 4.20$; Found: $\mathrm{C}, 50.27, \mathrm{H}, 3.98, \mathrm{~N}, 4.10$.

Stoichiometric Reaction of 14 with $\left[\mathrm{Ph}_{2} \mathbf{I}\right] \mathrm{BF}_{4}$. Complex 14 (15.0 mg, $0.02 \mathrm{mmol}, 1$ equiv), $\left[\mathrm{Ph}_{2} \mathrm{I}\right] \mathrm{BF}_{4}(61.1$ $\mathrm{mg}$, $0.17 \mathrm{mmol}$, 3.2 equiv per $\mathrm{Pd}$ ), and $3(19.0 \mathrm{mg}, 0.11 \mathrm{mmol}, 2.5$ equiv per $\mathrm{Pd}$ ) were combined in $\mathrm{AcOH}$ $(0.37 \mathrm{~mL})$ in a $2 \mathrm{~mL}$ vial equipped with a small magnetic stir bar. The vial was sealed with a Teflon-lined cap and heated at $100^{\circ} \mathrm{C}$ for $12 \mathrm{hr}$. The reaction was cooled to room temperature and analyzed by gas chromatography, which showed $90 \%$ yield of 1a (determined relative to an internal standard). Significant quantities of phenylated 3 (product 3a) were also observed by GC (as expected since an excess of oxidant was utilized). Importantly, when $\left[\mathrm{Ph}_{2} \mathrm{I}\right] \mathrm{BF}_{4}$ was replaced with $\mathrm{Ph}-\mathrm{I}$ or Ph-OTf under otherwise identical conditions $<1 \%$ of product 1a was observed by GC.

When the stoichiometric reaction between 14 and $\left[\mathrm{Ph}_{2} \mathrm{I}\right] \mathrm{BF}_{4}$ reaction was conducted in the absence of added substrate 3 (under the following conditions: complex 14 (1 equiv, $0.02 \mathrm{mmol}$ ), $\left[\mathrm{Ph}_{2} \mathrm{I}\right] \mathrm{BF}_{4}(1.2$ equiv per $\mathrm{Pd}, 0.05 \mathrm{mmol}), \mathrm{AcOH}(0.37 \mathrm{~mL}), 12 \mathrm{hr}, 100^{\circ} \mathrm{C}$ ) product 1a was obtained in $20 \%$ yield (determined relative to an internal standard) as the major product detectable by GC analysis. ${ }^{1} \mathrm{H}$ NMR spectroscopy and electrospray mass spectrometry revealed a complex mixture of additional high molecular weight organic products, and the MS data is consistent with the formation of a mixture of polyphenylated momomers and dimers of $\mathbf{1}$. While the origin of these products and the details of this reactivity remains under investigation, we hypothesize that added 3 may act to trap reactive cationic palladium species (generated after initial $\mathrm{C}-\mathrm{C}$ bond forming reductive elimination) that may be responsible for producing these polyphenylated products. Notably, under catalytic conditions, a large excess of substrate is present relative to catalyst, so such reactive species are expected to be trapped rapidly in a productive manner. 


\section{Reactions with Mixed Iodonium Reagents [Ph-I-Ar]BF 4}

Reaction of 1 with [Ph-I-Ar]BF 4 . Substrate 1 (10.0 mg, 0.059 mmol, 1 equiv), [Ph-I-Ar]BF $(0.071$ mmol, 1.20 equiv), and $\mathrm{Pd}(\mathrm{OAc})_{2}(0.700 \mathrm{mg}, 0.0031 \mathrm{mmol}, 5 \mathrm{~mol} \%)$ were combined in $\mathrm{AcOH}(0.49 \mathrm{~mL})$ in a $2 \mathrm{~mL}$ vial equipped with a small magnetic stir bar. The vial was sealed with a Teflon-lined cap and heated at $100^{\circ} \mathrm{C}$ for $12 \mathrm{hr}$. The reaction was cooled to room temperature and analyzed by gas chromatography. The yields of the products were determined by integration relative to a GC standard (2-phenylpyridine) and are \pm approximately $10 \%$.

Preliminary experiments were conducted to compare the electronic effects of aryl transfer in our $\mathrm{C}-\mathrm{H}$ activation/arylation reactions to those in a reaction reported to proceed by a $\mathrm{Pd}(\mathrm{II}) / \mathrm{Pd}(0)$ catalytic cycle. We selected the Suzuki reaction between phenyl boronic acid and [Ph-I-Ar] BF 4 for these studies. ${ }^{10}$ This reaction was first examined under our standard $\mathrm{C}-\mathrm{H}$ activation/arylation conditions $(0.12 \mathrm{M}$ in $\mathrm{AcOH}$, $100^{\circ} \mathrm{C}, 12 \mathrm{hr}$ ), in order to allow direct comparison between the results; however, no coupling products were observed by GC under these conditions. As such, we examined the selectivity of this reaction in $\mathrm{DME} / \mathrm{H}_{2} \mathrm{O}$ at room temperature (see below) with the series of iodonium salts examined in Table S1. Notably, our reaction conditions differ somewhat from those in the original paper, as we used the $\mathrm{BF}_{4}$ salts of the iodonium reagents; however, we feel that these were more relevant for direct comparison to the $\mathrm{C}-\mathrm{H}$ activation/arylation reactions. As summarized in Table S1, the Suzuki reactions proceed with different selectivity for transfer of Ar versus $\mathrm{Ph}$ relative to the $\mathrm{C}-\mathrm{H}$ activation/arylation reactions; however, a similar general trend in reactivity (where electron poor Ar groups are transferred in higher yield than electron rich Ar groups) is observed in both transformations.

Reaction of Phenylboronic acid with [Ph-I-Ar]BF4. Phenylboronic acid (20 mg, $0.16 \mathrm{mmol}$, 1.1 equiv),

[Ph-I-Ar] $\mathrm{BF}_{4}$ (0.15 mmol, 1.0 equiv), $\mathrm{Na}_{2} \mathrm{CO}_{3}\left(40 \mathrm{mg}, 0.30 \mathrm{mmol}, 2\right.$ equiv), and $\mathrm{Pd}\left(\mathrm{PPh}_{3}\right)_{4}$ (4.3 mg, 0.0037 mmol, $2.5 \mathrm{~mol} \%)$ were combined in DME $(1.69 \mathrm{~mL})$ and $\mathrm{H}_{2} \mathrm{O}(0.43 \mathrm{~mL})$ in a Schlenk flask under an $\mathrm{N}_{2}$ atmosphere. The reaction was stirred for $1 \mathrm{hr}$ at room temperature then analyzed by gas chromatography to determine the ratio of phenylated to arylated product (which is reported in Table S1, column 6 for each of the iodonium salts). These ratios are uncorrected for small differences in the response factors between the substituted biphenyl products. This assumption (of small differences in response factor) was made based on the small difference in response factor measured for the arylated phenyl pyridine products (1a1f) in Table S1. 
Table S1. Selectivity for Ph versus Ar Transfer in C-H Activation/ Arylation of 1 with [Ph-I-Ar] $\mathrm{BF}_{4}$
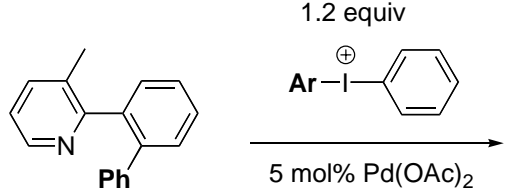

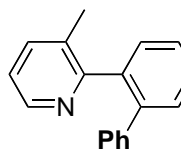

$1 \mathrm{a}$

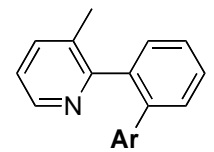

1b-f

\begin{tabular}{|c|c|c|c|c|c|}
\hline Entry & $\mathrm{Ar}$ & Yield $(\mathbf{1} \mathbf{a})^{b}$ & Yield $(\mathbf{1} \mathbf{b}-\mathbf{1} \mathbf{f})^{b}$ & Ratio (Ph/Ar Transfer) & Ratio $(\mathrm{Ph} / \mathrm{Ar}$ Suzuki) \\
\hline 1 & & $86 \%^{d}$ & - & - & - \\
\hline 2 & & $26 \%$ & $68 \%$ & $1: 2.6$ & $1: 1.5$ \\
\hline 3 & & $75 \%$ & $25 \%$ & $1: 0.33$ & $1: 1.1$ \\
\hline 4 & & $45 \%$ & $37 \%$ & $1: 0.83$ & 1: 1.3 \\
\hline 5 & & $63 \%$ & $44 \%$ & $1: 0.71$ & $1: 1.1$ \\
\hline 6 & & $75 \%$ & $25 \%$ & $1: 0.33$ & - \\
\hline 7 & & $73 \%$ & $23 \%$ & $1: 0.31$ & $1: 0.77$ \\
\hline
\end{tabular}

${ }^{a}$ Conditions: Substrate 1 (1.0 equiv, $0.12 \mathrm{M}$ in $\left.\mathrm{AcOH}\right)$, [Ph-I-Ar]BF 4 (1.1 equiv), $\mathrm{Pd}(\mathrm{OAc}) 2,100^{\circ} \mathrm{C}, 12 \mathrm{hr} .{ }^{b}$ Yields determined by GC based on integration versus an internal standard (errors $\pm \sim 10 \%$ ) and were calibrated versus authentic samples of each of the products. ${ }^{c}$ Ratio of phenylated to arylated product observed in Suzuki cross-coupling of $\mathrm{Ph}-\mathrm{B}(\mathrm{OH})_{2}$ with $[\mathrm{Ph}-\mathrm{I}-\mathrm{Ar}] \mathrm{BF}_{4}$ under the following conditions: $\mathrm{Ph}-\mathrm{B}(\mathrm{OH})_{2}(1.1$ equiv, $0.07 \mathrm{M}$ in 3/1 DME/ $\mathrm{H}_{2} \mathrm{O}$ ), [ $\mathrm{Ph}-\mathrm{I}-\mathrm{Ar}^{\mathrm{B}} \mathrm{BF}_{4}$ (1 equiv), $\mathrm{K}_{2} \mathrm{CO}_{3}$ (2 equiv), $\mathrm{Pd}\left(\mathrm{PPh}_{3}\right)_{4}(2.5 \mathrm{~mol} \%)$ at $25^{\circ} \mathrm{C}$ for $1 \mathrm{hr}$. Ratio determined by GC integration. ${ }^{d} \mathrm{GC}$ analysis shows traces of the diarylated product. 


\section{Solvent Optimization Studies}

Table S2. Solvent Optimization Studies with Substrate 1

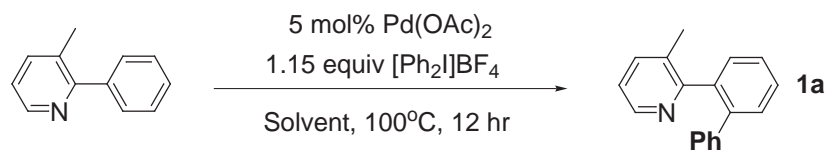

\begin{tabular}{ccc}
\hline Entry & Solvent & \% Conversion (GC) ${ }^{a}$ \\
\hline 1 & $\mathrm{AcOH}$ & $100 \%$ \\
2 & $50 \% \mathrm{AcOH} / 50 \% \mathrm{Ac}_{2} \mathrm{O}$ & $100 \%$ \\
3 & Benzene & $43 \%$ \\
4 & Toluene & $11 \%$ \\
5 & $\mathrm{CH}_{2} \mathrm{Cl}_{2}$ & $16 \%$ \\
6 & $\mathrm{CH}_{3} \mathrm{CN}$ & $14 \%$ \\
7 & $\mathrm{CHCl}_{3}$ & $18 \%$ \\
8 & $\mathrm{DMF}$ & $15 \%$ \\
\hline a \% conversion estimated by integration of GC peak areas \\
\multicolumn{2}{r}{ (not corrected for differences in response factor) }
\end{tabular}

Note: The optimal solvent/reaction conditions (eg, equiv of $\left.\left[\mathrm{Ph}_{2} \mathrm{I}\right] \mathrm{BF} \mathrm{F}_{4}\right)$ required for these reactions was found to vary somewhat as a function of substrate 


\section{Time Course - Reaction of $\mathrm{Pd}(\mathrm{OAc})_{2}$ or Catalyst 14 with Substrate 1}

Table S4. Time Course of Reaction with $\mathrm{Pd}(\mathrm{OAc})_{2}$ versus 14 as Catalyst

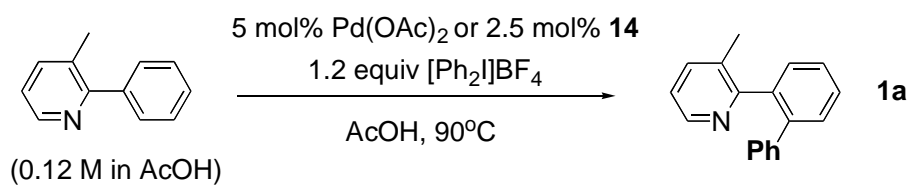

\% 1a vs Time

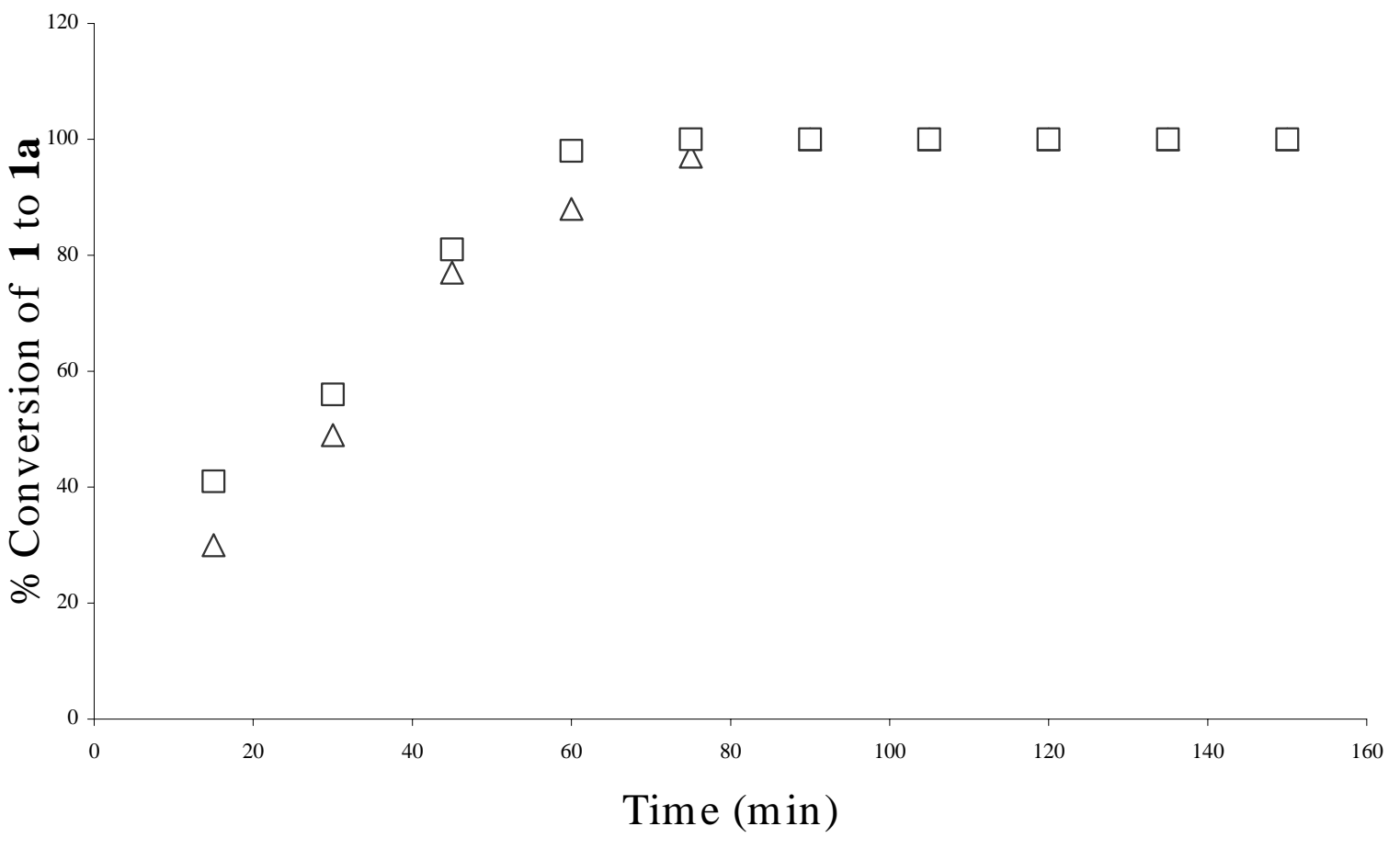

Legend

Squares $=$ Catalyst 14

Triangles $=\mathrm{Pd}(\mathrm{OAc})_{2}$ 


\section{References:}

1. Littke, A. F.; Dai, C.; Fu, G. C. J. Am. Chem. Soc. 2000, 122, 4020.

2. Littke, A. F.; Schwarz, L.; Fu, G. C. J. Am. Chem. Soc. 2002, 124, 6343.

3. Shakespeare, W. C. Tetrahedron Lett. 1999, 40, 2035.

4. Chen, D. W.; Ochiai, M. J. Org. Chem. 1999, 64, 6804.

5. Carroll, M. A.; Pike, V. W.; Widdowson, D. A. Tetrahedron Lett. 2000, 41, 5393.

6. McKillop, A.; Kemp, D. Tetrahedron 1989, 45, 3299.

7. Beringer, F. M.; Drexler, M.; Gindler, E. M.; Lumpkin, C. C. J. Am. Chem. Soc. 1953, 75, 2705.

8. Shah, A.; Pike, V. W.; Widdowson, D. A.; J. Chem. Soc., Perkin Trans. 1, 1997, 2463.

9. For example, see: Sandin, R. B.; McClure, F. T.; Irwin, F. J. Am. Chem. Soc. 1939, 61, 2944.

10. Kang, S.-K.; Lee, H.-W.; Jang, S.-B.; Ho, P.-S. J. Org. Chem. 1996, 61, 4720. 